\title{
Physicochemical Properties and Fatty Acid Profile of Shea Butter and Fluted Pumpkin Seed Oil, a Suitable Blend in Bakery Fat Production
}

\author{
Chibor Bariwere Samuel*, Kiin-Kabari David Barine, Eke-Ejiofor Joy \\ Department of Food Science and Technology, Rivers State University of Science and Technology, Port Harcourt, Nigeria
}

\section{Email address:}

bariwere@live.com (C. B. Samuel)

${ }^{*}$ Corresponding author

\section{To cite this article:}

Chibor Bariwere Samuel, Kiin-Kabari David Barine, Eke-Ejiofor Joy. Physicochemical Properties and Fatty Acid Profile of Shea Butter and Fluted Pumpkin Seed Oil, a Suitable Blend in Bakery Fat Production. International Journal of Nutrition and Food Sciences.

Vol. 6, No. 3, 2017, pp. 122-128. doi: 10.11648/j.ijnfs.20170603.12

Received: February 27, 2017; Accepted: March 11, 2017; Published: March 28, 2017

\begin{abstract}
Shea nuts (Vitellaria paradoxa) were cracked and sorted. Fluted pumpkin seeds (Telfairia occidentalis Hook) were dehulled and washed. The Shea kernel and Telfairia cotyledons were oven dried $\left(60^{\circ} \mathrm{C}, 24 \mathrm{~h}\right)$ separately in a hot air oven, milled into flour and oil extracted. Crude palm oil extracted from the palm fruit was used as control. The oil samples were analyzed for chemical composition, physical properties, and fatty acid profile. Shea nut oil (Shea butter) gave $58.00 \%$ ether extract, $0.88 \%$ free fatty acids, $1.7 \mathrm{mgKOH} / \mathrm{g}$ acid value, $1.03 \mathrm{mEqO}_{2} / \mathrm{kg}$ peroxide value, $70.00 \mathrm{~g} / 100 \mathrm{~g}$ iodine value, $227.94 \mathrm{mgKOH} / \mathrm{g}$ saponification value, $0.95 \%$ Unsaponifiable matter, and $226.17 \mathrm{mgKOH} / \mathrm{g}$ ester value. Fluted pumpkin seed oil gave $52.60 \%$ ether extract, $0.71 \%$ free fatty acids, $1.41 \mathrm{mgKOH} / \mathrm{g}$ acid value, $1.17 \mathrm{mEqO}_{2} / \mathrm{kg}$ peroxide value, $119.67 \mathrm{~g} / 100 \mathrm{~g}$ iodine value, $179.04 \mathrm{mgKOH} / \mathrm{g}$ saponification value, $0.57 \%$ Unsaponifiable matter, and $177.63 \mathrm{mgKOH} / \mathrm{g}$ ester value. The iodine value of Shea butter and Telfairia seed oil were significantly $(\mathrm{p}<0.05)$ higher than that of the control which gave $57.33 \mathrm{~g} / 100 \mathrm{~g}$ iodine value. Shea butter also gave 1.461 refractive index, $0.927 \mathrm{~g} / \mathrm{ml}$ density, $36.57^{\circ} \mathrm{C}$ slip melting point, $211.00^{\circ} \mathrm{C}$ smoke point, $83.92 \mathrm{cSt}$ kinematic viscosity, and 4red and 20yellow lovibond colour. Fluted pumpkin seed oil gave 1.463 refractive index, $0.903 \mathrm{~g} / \mathrm{ml}$ density, $18.60^{\circ} \mathrm{C}$ slip melting point, $244.50^{\circ} \mathrm{C}$ smoke point, $34.98 \mathrm{cSt}$ kinematic viscosity, and 5red and 20yellow lovibond colour. Shea butter gave 50.6\% total saturated fatty acids, and $49.1 \%$ total unsaturated fatty acids, with stearic (45.8\%) and oleic (42.5\%) as the predominant saturated, and unsaturated fatty acids respectively. Fluted pumpkin seed oil gave $18.4 \%$ total saturated fatty acids, and $80.2 \%$ total unsaturated fatty acids, with palmitic (17.5\%) and linoleic $(62.4 \%)$ as the predominant saturated, and unsaturated fatty acids respectively. Shea butter, with a melting point of $36.57^{\circ} \mathrm{C}$ will provide a good solid base for bakery fat production, while Telfairia seed oil with iodine value of $119.33(\mathrm{~g} / 100 \mathrm{~g})$ will provide healthy fatty acids and the needed plasticity. A blend of Shea butter and fluted pumpkin seed oil in bakery fat production has potential to improve the nutritional and functional properties of the end products.
\end{abstract}

Keywords: Shea Butter, Fluted Pumpkin, Physicochemical, Fatty Acid Profile, Bakery Fat

\section{Introduction}

Shea butter and Fluted Pumpkin seeds are good sources of fats and oil. Shea butter is obtained from the nuts of Shea tree (Vitellaria paradoxa), which exist in the wild in most parts of Africa [1]. It is a native of the dry Savanna belt of West Africa [2], where it grows wild across a $5000 \mathrm{~km}$ wide belt of Savanna [3], inhabiting West African Countries of Senegal, Burkina Faso, Cote d'Ivoire, Mali, Ghana, Togo, Benin, Nigeria, Cameroon,
Niger, and further east into Sudan, Uganda and Ethiopia [4]. Shea butter is solid at room temperature, edible and used in food preparation in Africa [5]. It is commonly used as a domestic frying and cooking oil, and in the industries for cosmetics and medicinal purposes. There are no report of allergic reaction owing to consumption of Shea butter or its products [6].

Fluted pumpkin (Telfairia occidentalis Hook F) is a tropical crop that belongs to the Cucurbitaceae family, known for its great genetic diversity and widespread adaptation [7]. 
It is reported to be indigenous to the west tropical rain forest area of Nigeria [8]. It is grown in Nigeria for its vegetable and oil bearing seeds. Although the fruit is inedible, the seeds produced by the gourd are high in protein and fat [9] and can therefore contribute to a well-balanced diet. The blend of Shea butter (a solid fat) and fluted pumpkin seed oil, rich in essential polyunsaturated fatty acids is expected to produce bakery shortening with improved functionalities, nutrition and health value.

Bakery fats (shortenings) are tailored fat systems, whose nutritional and functional properties have been modified in order to deliver specific functional needs; as tenderizing agents, facilitate aeration, texture, mouthfeel, carry flavours and colours, provide a heating medium, and structural integrity to pies, breads, pasta and other bakery products [10]. This modification gives desirable consistency and keeping quality. Use of Shea nut and Telfairia seed oil in bakery fat production will further enhance the utilization of these agricultural raw materials. It will also provide a brand that will compete favorably with the predominant palm stearin based margarine and shortenings in Nigeria market. The objective of this study was to evaluate the physicochemical properties and fatty acid profile of Shea butter and fluted pumpkin seed oil, as fat blend in bakery fat production.

\section{Materials and Methods}

Healthy nuts of the Shea tree were procured from Minna, Niger State, while mature, freshly harvested fluted pumpkin fruits were purchased from Bori market in Rivers State. The Shea nuts were cracked and sorted. The Telfairia seeds were dehulled and washed. The Shea kernel and Telfairia cotyledons were both oven dried at $60^{\circ} \mathrm{C}$, for $24 \mathrm{~h}$, separately in a hot air oven (model QUB 305010G, Gallenkamp, UK), ground using a laboratory mill (model MXAC2105, Panasonic, Japan), this was followed by oil extraction as described by AOAC [11].

\subsection{Physicochemical Properties}

Physicochemical properties including; acid value, iodine value, free fatty acids, peroxide value, Saponification value, Unsaponifiable matter, melting point, Refractive index and density were determined by the method of AOAC [11]. Viscosity measurement (in centistokes, cSt) was performed using an Ubbelohde glass capillary viscometer (size 2. A149, Cannon instrument, PA, USA). Refractive index was performed using the Abbe Refractometer model 2WAJ (Wincom, China).

\subsection{Fatty Acid Profile}

The individual fatty acids in the oil/fats were determine using the A. O. A. C [11] methods.

Fatty acid methyl esters (FAME) were prepared from the extracted fats/oil. In $50 \mathrm{ml}$ round bottom flasks, $50 \mathrm{mg}$ of each sample was kept in separate flasks and $3 \mathrm{ml}$ of sodium methylate solution $(0.5 \mathrm{~mol} / 1$ of methanolic solution of $\mathrm{NaOH})$ was added. The reaction medium was refluxed for 10 minutes; $3 \mathrm{ml}$ of acetyl chloride was added; mixture was refluxed again for 10 minutes and then cooled to ambient temperature; $8 \mathrm{ml}$ hexane and $10 \mathrm{ml}$ of distilled water was added and allowed to stand for 5 minutes to establish a two phase solution. The upper organic phase was recovered into a vial for GC analysis, using Agilent 7890A, coupled with flame-ionization detector (FID).

\subsection{Statistical Analysis}

All the analyses were carried out in triplicate. Data obtained were subjected to Analysis of variance (ANOVA), differences between means were evaluated using Tukey's multiple comparison test, and significance accepted at $\mathrm{p} \leq$ 0.05 level. The statistical package in Minitab 16 computer program was used.

\section{Results and Discussion}

\subsection{Chemical Properties of Shea Butter, Fluted Pumpkin Seed Oil and Crude Palm Oil}

\subsubsection{Ether Extract}

Table 1, shows the percentage ether extract of Shea nut oil as $58.00(\%)$, this value was higher than $56 \%, 53.56 \%$, and $47.5 \%$ reported by other researchers [12], [13], [14]

The fluted pumpkin seed oil gave an ether extract yield of $52.60(\%)$, this value was slightly lower than $54 \%$ earlier reported [15] but higher than $46.37 \%$ and $46.2 \%$ also reported [16], [17].

\subsubsection{Acid Value}

The acid value is a measure of the amount of potassium hydroxide (mg) necessary to neutralize the free acids in $1 \mathrm{~g}$ of fat [18]. The acid value of unrefined Shea butter is $1.76 \mathrm{mgKOH} / \mathrm{g}$, this value relates closely to $1.2 \mathrm{mgKOH} / \mathrm{g}$ earlier reported [14]. Higher values of $2.3-3.0 \mathrm{mgKOH} / \mathrm{g}$ had also been reported [13].

The acid value of the unrefined fluted pumpkin seed oil was $1.41 \mathrm{mgKOH} / \mathrm{g}$. this value is lower than $3.97,3.56,3.48$, and $2.22 \mathrm{mgKOH} / \mathrm{g}$ reported by earlier researchers [19], [20], [21], [7], [16]. Lower acid values of $0.76 \mathrm{mgKOH} / \mathrm{g}$ had also been reported [22].

The acid values (AV) of Shea butter and Fluted pumpkin seed oil were significantly $(p<0.05)$ lower than that of the control (crude palm oil) which gave AV of $7.29 \mathrm{mgKOH} / \mathrm{g}$.

A low AV means that an oil sample contains less free acids thus reducing its exposure to rancidification [23], [24]. The low acid value of Shea butter and fluted pumpkin seed oil shows that the fats are suitable for food and other industrial uses.

\subsubsection{Free Fatty Acids}

The free fatty acid content of unrefined Shea butter and fluted pumpkin seed oil were reported as $0.88 \%$ and $0.71 \%$ respectively, these were significantly $(\mathrm{p}<0.05)$ lower than the CPO $(3.33 \%)$. FFA of $0.71 \%$ compares with $0.73 \%$ recorded for cashew nut seed oil [25].

The low FFA of unrefined Shea butter and fluted pumpkin seed oil enhances their suitability for bakery fat and other food product formulations. The cost and energy required for refining 
and modifications will be much less than that needed for palm oil refining.

\subsubsection{Peroxide Value (PV)}

The PV of Shea butter was $1.03 \mathrm{mEqO}_{2} / \mathrm{kg}$, this value was significantly $(\mathrm{p}<0.05)$ lower than $1.53 \mathrm{mEqO}_{2} / \mathrm{kg}$ recorded by the control. PV of $1.03 \mathrm{mEqO}_{2} / \mathrm{kg}$ agrees with the range $(0.4-$ $2.57 \mathrm{mEqO}_{2} / \mathrm{kg}$ ) earlier reported for unrefined Shea butter [14].

The PV of fluted pumpkin seed oil was $1.17 \mathrm{mEqO}_{2} / \mathrm{kg}$. This value was also significantly $(\mathrm{p}<0.05)$ lower than the CPO $\left(1.53 \mathrm{mEqO}_{2} / \mathrm{kg}\right)$.

The PV of the Shea butter and fluted pumpkin seed oil were much lower than $10 \mathrm{mEqO}_{2} / \mathrm{kg}$, which is the maximum allowable standard of PV for edible oil [28]. Peroxide value (PV) is the milliequivalent $(\mathrm{mEq})$ of oxygen per $100 \mathrm{~g}$ of fat, it is used to indicate the degree to which a fat has been oxidized [26]. Oxidation of an unsaturated oil takes place via the formation of hydroperoxides. The hydroperoxides been the primary products of oxidation do not have any off-flavour [27].

\subsubsection{Iodine Value (IV)}

Iodine value is a simple chemical constant used to measure unsaturation or the average number of double bonds in an oil sample. It is defined as the number of grams of iodine that could be added to $100 \mathrm{~g}$ of oil [26], [29].

The iodine value of Shea nut oil (Shea butter) was $70.00 \mathrm{~g} / 100 \mathrm{~g}$. This value was significantly $(\mathrm{p}<0.05)$ higher than the crude palm oil $(57.33 \mathrm{~g} / 100 \mathrm{~g})$. IV of $70.00 \mathrm{~g} / 100 \mathrm{~g}$ was higher than $60.37 \mathrm{~g} / 100 \mathrm{~g}, 61.00 \mathrm{~g} / 100 \mathrm{~g}$ and $61.31 \mathrm{~g} / 100 \mathrm{~g}$ earlier reported [1], [31], [14]. Shea butter with IV of $83.3 \mathrm{~g} / 100 \mathrm{~g}$ had also been reported [31]. IV of 70 fall within $58-72 \mathrm{~g} / 100 \mathrm{~g}$ which is the acceptable range of IV for Shea butter at international level [32].

The IV of Shea nut oil was significantly $(p<0.05)$ lower than that obtained for fluted pumpkin seed oil $(119.67 \mathrm{~g} / 100 \mathrm{~g})$.

The low iodine value of Shea nut oil indicates that the oil is rich in saturated fatty acids, which ensures stability against oxidation and rancidity of foods prepared with the oil [33]. It also act as a good source of solid fat for shortening and margarine production.

High iodine value of fluted pumpkin seed oil $(119.67 \mathrm{~g} / 100 \mathrm{~g})$, indicates that the oil is rich in polyunsaturated fatty acids, which enhances the nutritional value of food products in which it is used. The IV of fluted pumpkin seed oil $(119.67 \mathrm{~g} / 100 \mathrm{~g})$ compares with IV of 119.92g/100g recorded for sunflower seed oil [34].

\subsubsection{Saponification Value (SV)}

The saponification value (SV) of Shea nut oil was $227.94 \mathrm{mgKOH} / \mathrm{g}$, this value relates to $227.49 \mathrm{mgKOH} / \mathrm{g}$ recorded for groundnut [35]. SV of $227.94 \mathrm{mgKOH} / \mathrm{g}$ was significantly $(\mathrm{p}<0.05)$ higher than $200.47 \mathrm{mgKOH} / \mathrm{g}$ given by the control (CPO) sample. High saponification value is an indication of oil suitability for industrial use.

The SV of fluted pumpkin seed oil was $179.04 \mathrm{mgKOH} / \mathrm{g}$, this value agreed with $179.04 \mathrm{mgKOH} / \mathrm{g}$ reported by earlier researchers [21], [7].

\subsubsection{Unsaponifiable Matter (USM)}

Unsaponifiable matter refer to substances dissolved in the fat, which are insoluble in aqueous solution but soluble in organic solvent after saponification [36].

The percentage USM in Shea nut oil was $0.95 \%$, this was significantly $(\mathrm{p}<0.05)$ higher than that given by the crude palm oil of $0.55 \%$. The USM of Shea butter had been reported to be relatively higher than other vegetable oils, given up to 4\% USM [38]. The high USM content of Shea butter shows that the oil is rich in desirable bioactive components such as; antioxidants, antimicrobial, and antiinflamatory substances [38] as well as the fat soluble vitamins. It has also been used to lower cholesterol levels by a pharmaceutical company, BSP Pharma [39].

The percentage USM in fluted pumpkin seed oil was $0.57 \%$, this value agreed with the range $0.2-0.8 \%$ reported for groundnut, and $0.5 \%$ reported for soybean [36]. The Unsaponifiable fraction comprises only a small part of fluted pumpkin seed oil compared to triglyceride fraction.

\subsubsection{Ester Value (EV)}

The ester value of a fat is a function of the saponification value and the acid value.

It is an indication of the saponifiable fatty acids excluding the free acids of the fat [40].

The ester value of Shea nut oil is $226.17 \mathrm{mgKOH} / \mathrm{g}$, this value was significantly $(\mathrm{p}<0.05)$ higher than the control crude palm oil $(193.18 \mathrm{mgKOH} / \mathrm{g})$. The $\mathrm{EV}$ of fluted pumpkin seed oil was $177.63 \mathrm{mgKOH} / \mathrm{g}$. The high ester value of Shea butter and fluted pumpkin seed oil is an indication that the fats are suitable for culinary purposes.

Table 1. Chemical properties of Shea butter, Fluted pumpkin seed oil, and crude palm oil.

\begin{tabular}{lllllllll}
\hline OIL & AV & FFA & PV & IV & SV & USM & EV & EE \\
\hline SAMPLE & $(\mathrm{mgKOH} / \mathrm{g})$ & $(\%)$ & $\mathrm{mEqO} / \mathrm{kg})$ & $(\mathrm{g} / 100 \mathrm{~g})$ & $(\mathrm{mKOH} / \mathrm{g})$ & $(\%)$ & $(\mathrm{mgKOH} / \mathrm{g})$ & $(\%)$ \\
FPSO & $1.41^{\mathrm{c}} \pm 0.02$ & $0.71^{\mathrm{c}} \pm 0.01$ & $1.17^{\mathrm{b}} \pm 0.06$ & $119.67^{\mathrm{a}} \pm 0.58$ & $179.04^{\mathrm{c}} \pm 0.83$ & $0.57^{\mathrm{b}} \pm 0.02$ & $177.63^{\mathrm{c}} \pm 0.85$ & $52.60^{\mathrm{b}} \pm 0.53$ \\
SNO & $1.76^{\mathrm{b}} \pm 0.04$ & $0.88^{\mathrm{b}} \pm 0.02$ & $1.03^{\mathrm{b}} \pm 0.06$ & $70.00^{\mathrm{b}} \pm 1.00$ & $227.94^{\mathrm{a}} \pm 0.38$ & $0.95^{\mathrm{a}} \pm 0.02$ & $226.17^{\mathrm{a}} \pm 0.38$ & $58.00^{\mathrm{a}} \pm 0.40$ \\
CPO & $7.29^{\mathrm{a}} \pm 0.06$ & $3.33^{\mathrm{a}} \pm 0.03$ & $1.53^{\mathrm{a}} \pm 0.12$ & $57.33^{\mathrm{c}} \pm 0.75$ & $200.47^{\mathrm{b}} \pm 0.65$ & $0.55^{\mathrm{b}} \pm 0.02$ & $193.18^{\mathrm{b}} \pm 0.64$ & $\mathrm{ND}$ \\
\hline
\end{tabular}

Values are means \pm standard deviation of triplicate samples.

Mean values bearing the same superscript in the same Column do not differ significantly ( $\mathrm{p}>0.05)$.

Key: $\mathrm{FPSO}=$ Fluted pumpkin seed oil, $\mathrm{SNO}=$ Shea nut oil, $\mathrm{CPO}=$ Crude palm oil, $\mathrm{AV}=$ Acid value $\mathrm{FFA}=$ free fatty acid, $\mathrm{PV}=\mathrm{Peroxide}$ value, $\mathrm{IV}=\mathrm{Iodine}$ Value, $\mathrm{SV}=$ Saponification value, $\mathrm{USM}=$ Unsaponifiable matter, $\mathrm{EV}=$ ester value, $\mathrm{EE}=$ Ether extract, $\mathrm{ND}=$ not determined. 


\subsection{Physical Properties of Shea Butter, Fluted Pumpkin Seed Oil and Crude Palm Oil Refractive Index (RI)}

Table 2 shows the physical properties of samples with the RI of Shea butter as 1.461, while the RI of fluted pumpkin seed oil was 1.463 , these values were significantly $(p<0.05)$ higher than the control CPO. Refractive index of fat increases with increasing chain length and also with number of double bonds present in the oil [41]. RI also depend on the degree of unsaturation and the degree of conjugation of the oil [29].The high RI of fluted pumpkin seed oil shows that the oil contains more unsaturated fatty acids than Shea butter, and palm oil.

\subsubsection{Density (Dn)}

The density gives information on the weight of the fat and the solid content at a specified temperature. In Table 2, the density of Shea butter was $0.927 \mathrm{~g} / \mathrm{ml}$ at $30^{\circ} \mathrm{C}$. This was significantly higher than $0.900 \mathrm{~g} / \mathrm{ml}$ given by the control (crude palm oil).

The density of fluted pumpkin seed oil (FPSO) was $0.903 \mathrm{~g} / \mathrm{ml}$, which showed no significant $(\mathrm{p}>0.05)$ difference with the density of palm oil $(0.900 \mathrm{~g} / \mathrm{ml})$ at $30^{\circ} \mathrm{C}$.

\subsubsection{Slip Melting Point (SMP)}

The slip melting point is an indication of the temperature at which the fat soften or becomes sufficiently fluid to slip or flow. The slip melting point of Shea butter was $36.57^{\circ} \mathrm{C}$. This value was significantly $(\mathrm{p}<0.05)$ higher than the control (crude palm oil) with SMP of $32.57^{\circ} \mathrm{C}$. The melting value of Shea butter also compares with the range $\left(34-38^{\circ} \mathrm{C}\right)$ earlier reported [1]. This melting range show that Shea butter is a solid fat below $36^{\circ} \mathrm{C}$, and thus will act as a good source of solid fat for margarine and shortening production. While fluted pumpkin seed oil gave a melting point of $18.50^{\circ} \mathrm{C}$, which was significantly $(p<0.05)$ lower than the SMP of crude palm oil. The lower melting point of FPSO indicates that it has less resistance to shear stress, and thus its inclusion in table or bakery margarine blend will enhance plasticity.

\subsubsection{Smoke Point (SP)}

The smoke point is the temperature at which oil gives off a thin bluish smoke. When fat over heat, it breaks down/decompose into glycerol and its individual fatty acids. The glycerol is further hydrolyzed to a steel-blue acrolein smoke [42]. The smoke point indicates the temperature limit up to which that cooking oil can be used [43]. It correlate with the amount of free fatty acid in the oil [43]. The SP does tend to increase as the free fatty acid content decreases. The smoke point of Shea butter was $211.00^{\circ} \mathrm{C}$, this was significantly $(\mathrm{p}<0.05)$ lower than $230.05^{\circ} \mathrm{C}$ given by palm oil. Fluted pumpkin seed oil gave smoke point of $244.50^{\circ} \mathrm{C}$, this value compares with that reported earlier [7]. The relatively high smoke point of Shea butter and FPSO indicates that the oil can be used for a wide range of cooking applications.

\subsubsection{Viscosity (VS)}

The viscosity of fat is its resistance to flow. It increases with the molecular weight of the oil and decreases with increasing unsaturation and high temperature [44]. The viscosity of Shea butter was $83.92 \mathrm{cSt}$ (centi stokes) at $40^{\circ} \mathrm{C}$. This value was significantly higher than that of crude palm oil $(42.48 \mathrm{cSt})$. The high viscosity of Shea butter at $40^{\circ} \mathrm{C}$ shows high resistance to flow, this is an indication that Shea butter contains more saturated fatty acids and more solid fats at $40^{\circ} \mathrm{C}$, making it a suitable source of hard stock (solid fraction) for bakery shortening and margarine production.

Fluted pumpkin seed oil gave $34.98 \mathrm{cSt}$, which was significantly $(\mathrm{p}<0.05)$ lower than the control. Low viscosity of $32.22 \mathrm{cP}$ and $45 \mathrm{cSt}$ had been reported for FPSO [20]. The relatively low viscosity value of fluted pumpkin seed oil shows that the oil is light and probably highly unsaturated [45].

\subsubsection{Lovibond Colour Intensity}

The Lovibond colour of Shea butter was 4Red and 20Yellow, Telfairia seed oil 5Red and 20Yellow. The lovibond colour of unrefined Shea butter and fluted pumpkin seed oil (4red and 5red) were significantly $(\mathrm{p}<0.05)$ lower than that of crude palm oil (11red and 22yellow). This implies that it will be less expensive to bleach and refine Shea butter and Telfairia seed oil than palm oil.

Table 2. Physical properties of Shea butter, Fluted pumpkin seed oil, and crude palm oii.

\begin{tabular}{lllllll}
\hline OIL & RI & Ds & SMP & SMOK. P & VS & L. C \\
\hline SAMPLE & & $\mathbf{( g / m l )}$ & $\left({ }^{\circ} \mathbf{C}\right)$ & $\left({ }^{\circ} \mathbf{C}\right)$ & $(\mathbf{c S t})$ & \\
\hline FPSO & $1.463^{\mathrm{a}} \pm 0.001$ & $0.903^{\mathrm{b}} \pm 0.006$ & $18.60^{\mathrm{c}} \pm 0.40$ & $244.50^{\mathrm{a}} \pm 0.20$ & $34.98^{\mathrm{c}} \pm 0.63$ & $5 \mathrm{R}, 20 \mathrm{Y}$ \\
SNO & $1.461^{\mathrm{a}} \pm 0.001$ & $0.927^{\mathrm{a}} \pm 0.006$ & $36.57^{\mathrm{a}} \pm 0.59$ & $211.00^{\mathrm{c}} \pm 0.10$ & $83.92^{\mathrm{a}} \pm 0.36$ & $4 \mathrm{R}, 20 \mathrm{Y}$ \\
CPO & $1.456^{\mathrm{b}} \pm 0.001$ & $0.900^{\mathrm{b}} \pm 0.001$ & $32.57^{\mathrm{b}} \pm 0.71$ & $230.05^{\mathrm{b}} \pm 0.40$ & $42.48^{\mathrm{b}} \pm 0.63$ & $11 \mathrm{R}, 22 \mathrm{Y}$ \\
\hline
\end{tabular}

Values are means \pm standard deviation of triplicate samples.

Mean values bearing the same superscript in the same Column do not differ significantly $(\mathrm{p}>0.05)$.

Key: $\mathrm{FPSO}=$ Fluted pumpkin seed oil, $\mathrm{SNO}=$ Shea nut oil, $\mathrm{CPO}=$ Crude palm oil, $\mathrm{RI}=$ Refractive index, $\mathrm{Ds}=$ Density, $\mathrm{SMP}=\mathrm{Slip}$ melting point, $\mathrm{Smok} . \mathrm{P}=$ Smoke point, VS= Viscosity, L. C= Lovibond colour.

\subsection{Fatty Acid Profile of Shea Nut Oil (SNO) and Fluted Pumpkin Seed Oil (FPSO)}

As shown in Table 3, Shea nut oil (SNO) had 50.6\% saturated fatty acids, and $49.1 \%$ unsaturated fatty acids. The predominant saturated fatty acids in SNO was stearic acid $(45.8 \%)$, while the predominant unsaturated fatty acid in SNO was oleic acid (42.5\%). Fluted pumpkin seed oil (FPSO) had $18.4 \%$ saturated fatty acid and $80.2 \%$ 
unsaturated fatty acids. The predominant saturated fatty acid in FPSO was palmitic acid (17.5\%), while the predominant unsaturated fatty acid in FPSO was linoleic acid $(62.4 \%)$. High linoleic acid content $(64.4 \%)$ in fluted pumpkin seed oil had earlier been reported [7]. The linoleic acid content of FPSO was observed to be higher than that earlier reported for other vegetable oil noted for high linoleic acid content, such as; maize (58.5\%), and soybean oil $(54.3 \%)$ [7]. The high stearin fraction of Shea butter $(50.6 \%)$ makes it a suitable source of solid fat, for bakery fat and margarine production. The high linoleic acid content of FPSO (62.4\%) make it a rich source of essential fatty acid, this will enhance the nutritional value of the vegetable shortening.
Table 3. Fatty Acid profile of Shea butter and Fluted pumpkin seed oil.

\begin{tabular}{lll}
\hline FATTY ACIDS & & FAT SAMPLES \\
\hline$(\%)$ & SNO & FPSO \\
Myristic (C14:0) & 0.3 & 0.1 \\
Myristoleic $(\mathrm{C} 14: 1)$ & 0.5 & \\
Palmitic (C16:0) & 4.1 & 17.5 \\
Palmitoleic $(\mathrm{C} 16: 1)$ & & 1.2 \\
Stearic $(\mathrm{C} 18: 0)$ & 45.8 & 0.8 \\
Oleic $(\mathrm{C} 18: 1)$ & 42.5 & 14.1 \\
Linoleic $(\mathrm{C} 18: 2)$ & 6.1 & 62.4 \\
Linolenic $(\mathrm{C} 18: 3)$ & & \\
Arachidic $(\mathrm{C} 20: 0)$ & & \\
Paullinic (C20:1) & 0.6 & 2 \\
Lignoceric (C24:0) & & 1.5 \\
\hline
\end{tabular}

Key: $\mathrm{SNO}=$ Shea nut oil; FPSO= fluted pumpkin seed oil.

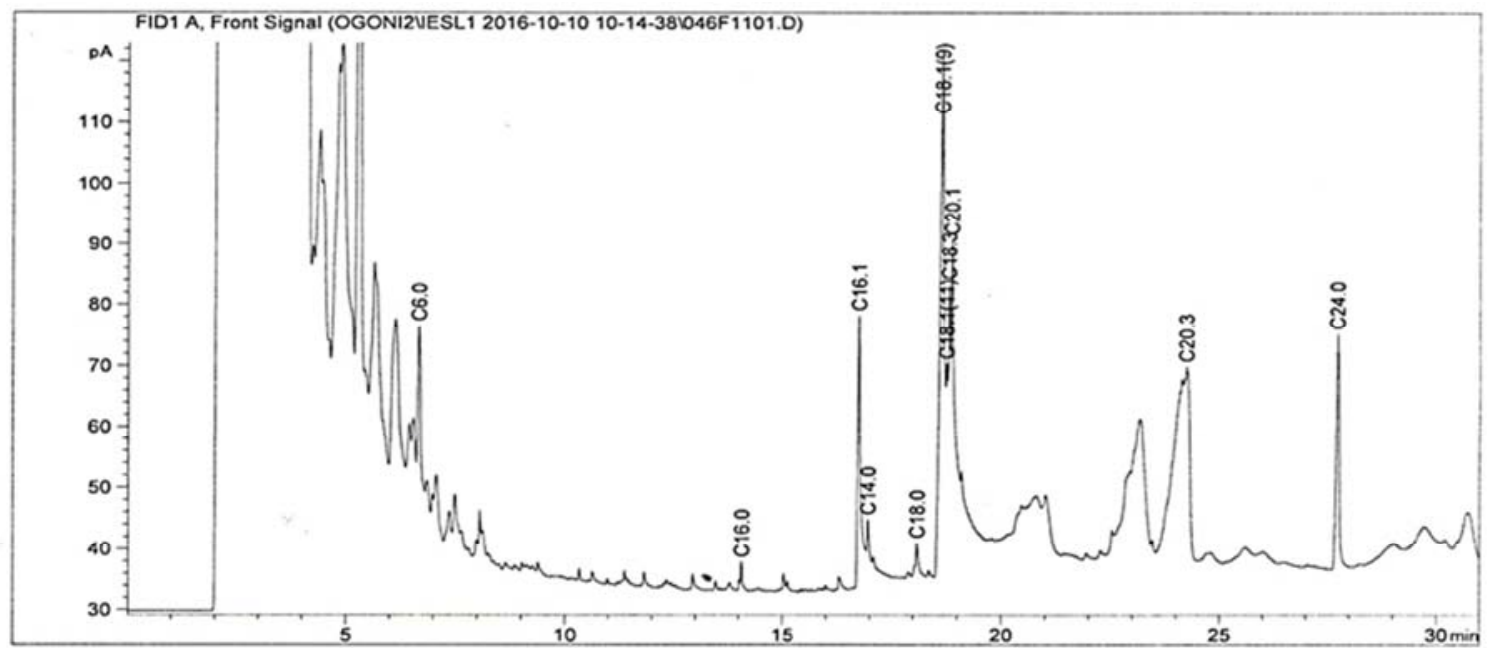

Figure 1. Fatty acid GC Chromatogram of Fluted pumpkin seed oil (FPSO).

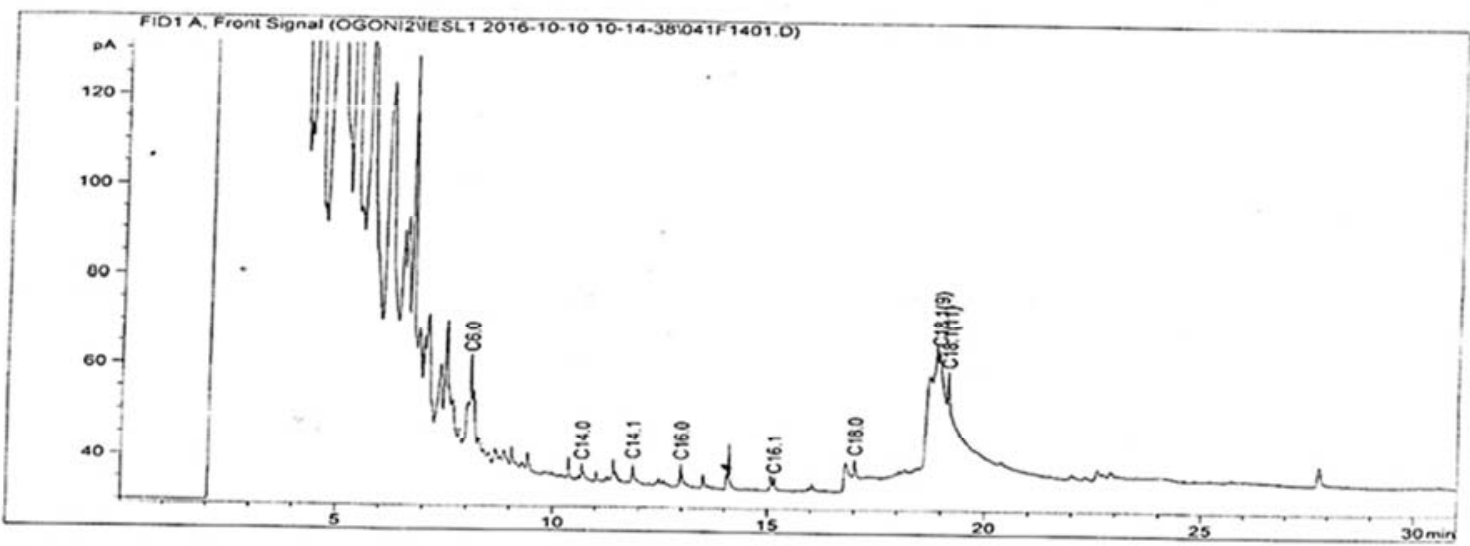

Figure 2. Fatty acid GC Chromatogram of Shea nut oil (SNO).

\section{4: Conclusion and Recommendation}

Shea nut oil has high recovery $(58.00 \%)$ and is chemically safe for culinary purposes. Its physicochemical properties enhances its potential for incorporation into human food products and other industrial purposes such as in drugs and cosmetics. The high concentration of long chain solid fat components (stearic acids) makes it a stable solid at room temperature and this enhances its usefulness in margarine, and bakery shortenings manufacturing. The use of Shea butter as a source of solid base stock in bakery fat production will not only eliminate trans-fat from partially hydrogenated hard stocks, but will ensure the use of the least deleterious saturated fatty acid (stearic acid), which is much healthier than palmitic and other saturated fatty acids, as regards cardiovascular health [2]. Fluted pumpkin seed oil has over $80 \%$ of unsaturated fatty acids, out of which over $62 \%$ is the 
polyunsaturated specie (linoleic acid). Linoleic acid is an essential fatty acid which is safe, heart friendly and nutritionally desirable. A blend of Shea butter and fluted pumpkin seed oil in bakery fat/shortening production will give a product better described as linoleic acid rich Shea and Telfairia oil (LARSTO) shortening.

\section{References}

[1] Obibuzur, J. U., Abigor, R. D., Omamor, I., Omoriyekemen, V., Okogbenin, E. A and Okunwaye, T. (2014). A. two- year seasonal survey of the quality of Shea butter produced in Niger State of Nigeria. African Journal of Food Science. 8(2): 64-74.

[2] Isreal, M. O. (2015). Shea butter: An opposite replacement for trans-fat in margarine. Journal of Nutrition and Food Science. S11:S11001 doi: 10.4172/2155-9600. 1000S11001.

[3] Maranz, S. and Wiesman, Z. (2003).Evidence of Indigenous selection and distribution of the Shea tree, Vitelleria paradoxa, and its potential significance to prevailing parkland Savanna tree patterns in sub- Saharan African north of equator. Journal of Biogeography. 30: 1505-1516.

[4] Goreja, W. G. (2004). Shea butter: The Nourishing properties of Africa's Best-Kept natural beauty. Amazing Herbs press. New York, N. Y.

[5] Abbiw, D. K.(1990). Useful plants of Ghana, West Africa. Uses of wildland cultivated plants. International Technology publication and the royal botanic gardens, Kew, London pp. 66-67.

[6] Essengue, S. B., Stechschuitte, D. and Olson, N. (2009). The use of Shea butter as an emollient for Eczema. Journal of Allergy and Clinical Immunology. 123: 145-148.

[7] Bello, M. o., Akindele, T. 1., Adeoye, D. O, and Oladinej, A. O. (2011). Physicochemical properties and fatty acid profile of seed oil of Telfairia Occidentalis Hook F. International Journal of Basic and Applied Science, 11 (06): 9-14.

[8] Giami, S. Y. and Barber, L. I. (2004). Utilization of protein concentrate from ungerminated and germinated fluted pumpkin (Telfairia occidentalis Hook F) seed in cookie formulation. Journal of the Science of Food and Agriculture, 84: 1901-1907.

[9] Giwa, S., Abdullah, L. C. and Adam, N. M. (2010). Investigating "Egusi"(Citrullus colocynthis L) seed oil as potential biodiesel feed stock. Energies 3: 607- 618.

[10] Rios, R. V., Pessanha, M. D. F., Almeida, P. F., Viana, C. L. and Lanne, S. C. (2014). Application of fat in some food products. Food Science and Technology (Campinas), 3 (1), 315 .

[11] AOAC (2012). Association of Official Analytical Chemist, official methods of Analysis, $19^{\text {th }}$ edition, Washington, D. C.

[12] Okullo, J. B. L., Hall, J. B. and Obua, J. (2004). Leafing, flowering and fruiting of Vitellaria paradoxa subsp. nilotica in Savanna parklands in Uganda. Agroforestry systems; 60: 77-91.

[13] Okullo, J. B. L., Omujai, F., Agea, J. G., Vuzi, P. C., Namutebi, A., Okello, J. B. and Nyanzi, S. A. (2010). Physico-chemical characteristics of Shea butter (Vitellaria
Paradoxa C. F. Gaertu) oil from the shea districts of Uganda. AJFAND, African Journal of Food Agriculture Nutrition and Development, 10(1), 2070-2084.

[14] Ikya, Jk., Umenger, L. N., and Iobee, A. (2013). Effect of extraction methods on the yield and quality characteristics of oils from shea nut. Journal of Food Resource Science, 2: 1-12.

[15] Giami S. Y., Chibor B. S., Edebiri K. E., and Achinewhu S. C, (1999). Changes in nitrogenous and other chemical constituents, protein fractions and in vitro protein Digestibility of germinated Fluted Pumpkin (Telfairia Occidentalis Hook) seed. Plant Foods for Human Nutrition 53, 333-342.

[16] Adejumor, B. A. and Oyedeji, O. O. (2015). Some Characteristics of Fluted Pumpkin oil extracted at three heating temperatures. International Journal of Innovation and Scientific Research, 17(2), 336-340.

[17] Okashi, V. E., Oguga, V. N., Ugian, E. A. and Njoku, O. U. (2013). Physico-chemical properties of fluted pumpkin (telfairia occidentalis Hook F) Seeds. The International Journal of Engineering and Science (IJES), 2(9), 36-38.

[18] Ikaya, J. K., Umengar, L. N. and Iobee, A. (2013). Effect of extraction methods on the yield and quality characteristics of oils from nut. Journal of Food Research Science, 2: 1-12.

[19] Akubugwo, I. E., Chinyere, G. C. and Ugbogu, A. E. (2008). Comparative Studies on Oil from some common Plant Seeds in Nigeria. Pakistan Journal of Nutrition, 7(4): 570-573.

[20] Bello, E. I., Anjorin, S. A., and Agge, M. (2012). Production of biodiesel from fluted pumpkin (Telfairia occidentalis Hook F) Seed oil International Journal of Mechanical Engineering, 2(1): 22-31.

[21] Muibat, O. B., Temitope, L. A., Deborah, O. A. and Abdullcabor, O. O. (2011). Physicochemical properties and fatty acid profile of seed oil of Telfairia occidentalis Hook F. International Journal of Basic and Applied Science, 11(06), 914.

[22] Eddy, N. O., Ukpong, J. A. and Ebenso, E. E. (2011). Lipids Characterization and Industrial Potentials of Pumpkin Seeds (Telfairia Occidentalis) and cashew Nuts (Anacardium occidentalis) European Journal of Chemistry, 8(4): 19861992.

[23] Asuquo, J. E., Anusien, A. C. I., and Etim, E. E. (2012). Comparative study of the effect of temperature on the adsorption of metallic soaps of shea butter, castor and rubber seed oil or to hematite. International Journal of Modern Chemistry, 3, 39-50.

[24] Anderson-Foster, E. N., Adebayo, A. S., and Justiz-Smith, N. (2012). Physico-chemical properties of Blighiasapida (ackee) oil extracted and its potential application as emulsion base. African Journal of Pharocology, 6, 200-210.

[25] Aletor, O., Agbede, J. O., Adeyeye, S. A. and Aletor, V. A. (2007). Chemical and Physio-chemical characterization of the floor and oils from whole and rejected cashew nuts cultivated in Southwest Nigeria. Pakistan Journal of Nutrition, 6(1), 8993.

[26] Ononogbu, I. C. (2002). Lipid in Human Existence. Ap Express, Nsukka pp. 1-80. 
[27] Gordon, M. D. (1993). Fats, fatty foods, In Ranken, M. D, and Kill, R. C (eds). Food Industries Manual $23^{\text {rd }}$ edi. Blacke Academic and professional, London, pp. 179-186.

[28] CODEX, (1993). Codex Alimentairus Commission. In: Ikya, J. K., Umengar, L. N., and Iorbee, A. Effect of Extraction Methods on the yield and Quality Characteristics of oils from shea nut. Journal of Food Resources Science, 2, 1-12.

[29] Shahidi, F. (2005). Quality Assurance of Fats and oils. In: Bailey's Industrial oil and fats products, Shahidi, F. (Ed). 6A Edn. John Wily and Sons Inc., USA.

[30] Kyari, M. Z. (2008). Extraction and Characterization of Seeds Oils. International Agrophysics, 22, 139-142.

[31] Olaniyan, A. M., and Oje, K. (2007). Quality Characteristics of Shea butter recovered from shea kernel through dry extraction process. Journal of Food Science and Technology, 44(4), 404-407.

[32] Fernande, H., Kashin, H., Akissoe, N., Coulibaly, O., Fandohan, P, and Hounhouigan, J. (2011). Effect of storage conditions on microbiological and physicochemical quality of Shea butter. Journal of Food Science and Technology, 48(3): $274-279$.

[33] Goh, E. (1994). Formulation of lauric oil containing food products and their performance. In: proceedings of world conference on lauric oils: Sources, processing and application s, Applewhite, T. H(ed). The American oil Chemists Society, USA, pp.38-103.

[34] Aboki, M. A., Mohammed, M., Musa, S. H., Zuru, B. S., Aliyu, H. M., Gero, M., Alibe, I. M., and Inuwa, B. (2012). Physicochemical and antiannus L) Seed Oil. International Journal of Science and Technology, 2(4), 151-154.

[35] Amo-Tanta, B. M. W., and Onigbinde, A. O. (2013). Physicochemical properties and fatty acid profile crude oil extracts from three vegetable seeds Pakistan Journal of Nutrition, 12(7), 647-650.

[36] Hamilton, R. J., Rossell, J. B. (1986). Analsis of oils and Fats. Elsevier Applied Science. New York. Chi.

[37] Alander, J. (2004). Shea butter- a multifunctional ingredient for food and cosmetics. Lipid Technology. 16(9), 202-205

[38] Nahm, H. S. (2011). Quality Characteristics of West African Shea butter (Vitellaria Paradox) and Approaches to School. New Brunswick, New Jersey.

[39] Masters, E. T., Yidane, J. A., Loveth, P. N. (2004). Reinforcing Sound Management through Trade: Shea Tree Products in Africa. Unasylva. 210: 46-52.

[40] Aremu, M. O., Ibrahim, H. and Bamidele, T. O. (2015). Physicochemical characteristics of the oils extracted from some Nigeria Plant Food A. Review. Chemical and Process Engineering Research 23: 2224-77467.

[41] Nielson, S. S. (1994). Introduction to the chemical Analysis of Foods. Chapman and Hall, New York, USA, pp. 93-207.

[42] Bockish, M. (1998). Fat and oils Handbook Champaign, IL: AOCS Press. Pp. 95-96.

[43] Thomes, A. (2002). Fats and fatty oils, Ullman's Encyclopedia of Industrial Chemistry, Weinheim: Wiley-VCH ISBN 3:52730673.

[44] Nourrechni H., Teoh B. C, and Clement L. D, (1992). Viscosity of vegetable oils and fatty acids. Journal of American Chemical Society, 69, 1184-1188.

[45] Nangbes J. C., Nvau J. B., Buba W. M, and Zukdimma A. N, (2013). Extraction and characterization of castor (Ricinus Communis) seed oil. The International Journal of Engineering and Science. IJES, 2(9), 105-109. 